\title{
Nutrient content in ora-pro-nóbis (Pereskia aculeata Mill.): unconventional vegetable of the Brazilian Atlantic Forest
}

\author{
Tibério Fontenele BARREIRA ${ }^{1}$, Galdino Xavier de PAULA FILHO ${ }^{2 \star}$ (D), Silvia Eloiza PRIORE ${ }^{3}$, \\ Ricardo Henrique Silva SANTOS ${ }^{4}$, Helena Maria PINHEIRO-SANT’ANA ${ }^{3}$
}

\begin{abstract}
Ora-pro-nóbis (Pereskia aculeata Mill.) is an unconventional vegetable found in the Brazilian Atlantic Forest and consumed, mainly by the rural population who lives in this biome. The present study investigated the nutritional value and contribution potential this species to the recommendations of daily nutrient intake for adults. Moisture and ash content were determined by gravimetry after oven drying and muffle incineration, respectively. Proteins were determined by the micro-Kjeldhal method; lipids by gravimetric lipids using soxhlet extractor; Total dietary fiber (TDF) by non-enzymatic gravimetry; Carotenoids and vitamin C by High Performance Liquid Chromatography (HPLC) with Diodes Array Detector; Vitamin E by HPLC and fluorescence detection; and minerals by inductively coupled plasma atomic emission spectrometry (ICP-AES). Ora-pro-nóbis

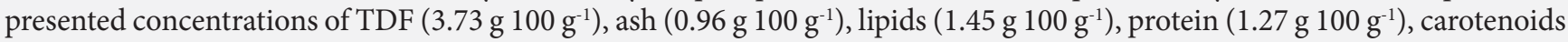



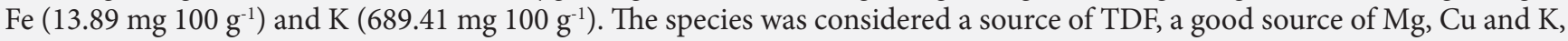
and an excellent source of vitamin A, Ca, Mn, Fe and Se.
\end{abstract}

Keywords: Pereskia aculeata Mill.; carotenoids; vitamins; minerals.

Practical Application: The work shows a complete study about the chemical composition (moisture content, total dietary fiber, lipids, proteins, carbohydrates and ash), carotenoids ( $\alpha$-carotene, $\beta$-carotene, $\beta$-cryptoxanthin and lycopene) and minerals (P, K, Ca, Mg, Cu, Fe, Zn, Mn, Na, Cr, Se and Mo) in ora-pro-nóbis, and their contribution to the Daily Recommendation of Nutrients in adults 19 to 30 years.

\section{Introduction}

A diversity of unconventional vegetable species can be found in the Atlantic Forest biome. Those species are still widely consumed mainly by the populations living in the rural area of this region (Barreira et al., 2015). It is observed that the use of these species is directly related to the dietary habits and that they can present important contribution to the strategies of food and nutritional security of the families that consume them (Paula et al., 2015).

Amid these vegetables, Pereskia aculeata, a species of the Cactaceae family, with a herbaceous growth habit, stands out. It is found in native environments, and grown in vegetable gardens, usually consumed braised and added to sauces and broths (Barreira et al., 2015).

Like other unconventional vegetables, Pereskia aculeata has been used for several generations as food resources. However, there is a lack of studies that report the nutritional value of this species, and evaluate its contribution to the recommendations of nutrient intake for the human organism. The state of the art on this crop has some works related only to the concentration of some nutrients (Takeiti et al., 2009), and on the use of this species for medicinal purposes in which present healing (Carvalho et al., 2014) and anti-inflammatory activities (Pinto et al., 2015).

So, the present study investigated the centesimal composition, the concentration of carotenoids, vitamin $\mathrm{C}$, vitamin $\mathrm{E}$ and minerals in Pereskia aculeata plants collected from natural environments of the Brazilian Atlantic Forest, and it analyzed their contribution to nutrient intake in 19-30-year-old adults.

\section{Material and methods}

\subsection{Sample collection and preparation}

Samples of Pereskia aculeata were collected in November 2012, in the rural area of the city of Viçosa ( $20^{\circ} 45^{\prime} 14^{\prime \prime} \mathrm{S}$ and $\left.42^{\circ} 52^{\prime} 44^{\prime \prime} \mathrm{W}\right)$, Minas Gerais, Brazil. The samples were transported to the laboratory in Styrofoam boxes containing dry ice within two hours after collection, washed in running water and after that, dried with paper towel. Then, they were homogenized in a food processor, packed in polyethylene bags, wrapped in aluminum foil and stored in a freezer $\left(-18 \pm 1^{\circ} \mathrm{C}\right)$.

${ }^{3}$ Departamento de Nutrição e Saúde, Universidade Federal de Viçosa - UFV, Viçosa, MG, Brasil

${ }^{4}$ Departamenta de Agronomia, Universidade Federal de Viçosa - UFV, Viçosa, MG, Brasil

*Corresponding author: galdinoxpf@gmail.com 
Analyses of vitamin $\mathrm{C}$ and carotenoid were performed within $36 \mathrm{~h}$ after collection, while vitamin $\mathrm{E}$ analysis were performed within $72 \mathrm{~h}$ after collection. Analyzes of the centesimal and mineral composition were performed within 120 hours after collection.

\subsection{Centesimal composition analysis}

Analyses of moisture, ash, protein and lipid were carried out in three replicates according to the methods of the Association of Official Analytical Chemists (2010).

Moisture was determined in oven at $65 \pm 1{ }^{\circ} \mathrm{C}$ for $72 \mathrm{~h}$ and ashes in a muffle oven at $550^{\circ} \mathrm{C}$ for $6 \mathrm{~h}$. Protein concentration was determined by the micro-Kjeldhal method in which crude protein was calculated by multiplying the nitrogen $(\mathrm{N})$ content by 6.25 . Total dietary fiber content was determined using the non-enzymatic gravimetric method (Guerra et al., 2004).

Carbohydrates were calculated by difference using the equation: [100 -\% moisture -\% lipids - $\%$ protein -\%TDF -\% ash]. The caloric density was estimated considering the conversion factors of $4 \mathrm{kcal} \mathrm{g}^{-1}$ protein or carbohydrate and $9 \mathrm{kcal} \mathrm{g}^{-1}$ lipids (Frary \& Johnson, 2005).

\subsection{Extraction and analyses of carotenoids and vitamins}

Carotenoids were extracted in acetone and transferred to petroleum ether (Rodriguez-Amaya et al., 1976). Vitamin A value was calculated according to the recommendations of the U.S. Institute of Medicine (2001). Vitamin C was analyzed as ascorbic acid (AA) and extracted in buffer solution (3\% metaphosphoric acid, $8 \%$ acetic acid, $0.3 \mathrm{~N}$ sulfuric acid and $1 \mathrm{mM}$ EDTA) (Campos et al., 2009). For the analysis of AA, the chromatographic conditions proposed by Campos et al. (2009) was used.

This study investigated the complete profile of vitamin $\mathrm{E}$ $(\alpha-, \beta-, \gamma-$ and $\delta$ - tocopherols and tocotrienols) in Pereskia aculeata. For extraction and analysis, the technique described by Pinheiro-Sant'Ana et al. (2011) was adopted.

Carotenoid and vitamin $\mathrm{C}$ analyzes were performed in a High-Performance Liquid Chromatography (HPLC) system composed of a high-pressure pump (LC 10AT VP); 50- $\mu \mathrm{L}$ loop auto-injector (SIL-10AF) and DAD-diodes array detector (SPD-M10A). In the vitamin E analysis, a CLAE system composed of a high-pressure pump with valve for a low-pressure quaternary gradient (LC 10AD VP) was used; automatic injector with 50$\mu \mathrm{L}$ loop (SIL-10AF) and fluorescence detector (rf-10A XL) was also used.

\subsection{Mineral determination}

The minerals (P, K, Ca, Mg, Zn, Mn, Fe, Cu, Na, Cr, Se and Mo) were extracted according to Gomes \& Oliveira (2011). The resulting solution was used reading of the concentration of minerals by ICP-AES,

For the quantification, analytical curves were constructed using mineral standards. Two multielement standard solutions (MESS) were prepared in 100 -mL flasks, as a result of the concentration of the minerals. MESS 1 was prepared for $\mathrm{Cr}$, Se, Mo, $\mathrm{Zn}, \mathrm{Cu}, \mathrm{Fe}$ and Mn. MESS 2 was prepared for $\mathrm{Na}, \mathrm{P}, \mathrm{Mg}, \mathrm{Ca}$ and $\mathrm{K}$. When mixing of MESS standards was finalized, the volume of the standards was filled with deionized water. For the construction of the analytical curves, increasing volumes of MESS 1 ( 0 to $2 \mathrm{~mL}$ ) and MESS 2 ( 0 to $20 \mathrm{~mL}$ ) were used, completed to $50 \mathrm{~mL}$ with white and deionized water to construct six points of the curve.

After the readings, the concentrations found in the samples, in $\mathrm{mg} \mathrm{L}^{-1}$, were converted to concentrations of minerals, considering the dilutions and their possible difference in relation to the white.

\subsection{Calculation of Pereskia aculeata potential contribution as a nutrient source}

The potential contribution of Pereskia aculeata as a nutrient source was estimated based on the Recommended Dietary Allowance (RDA) for 19-30-year-old adult men according to the recommendations of the U.S. Institute of Medicine (2001). Portions of Pereskia aculeata were calculated according to the Food Guide for the Brazilian Population (Brasil, 2008), considering the caloric density, where a portion of vegetables is equivalent to $30 \mathrm{kcal}$.

Pereskia aculeata was classified as a nutrient "source" when it presented the potential to supply from 5 to $10 \%$ of the Dietary Reference Intake (DRI); "good source" when it presented 10 to $20 \%$ potential of DRIs and as "excellent source", when it presented potential greater than $20 \%$ of DRIs (Philippi, 2008).

\subsection{Experimental design and statistical analysis of the data}

This study used a completely randomized design with five replicates for carotenoids and vitamins, and three replicates for centesimal composition. Descriptive statistics (mean, standard deviations and range of parameters) was used to present the results. Regarding linearity range of analytical standards, the data obtained from the peak areas were used for linear regression analysis and for calculation of the correlation coefficient $\left(\mathrm{R}^{2}\right)$. The statistical analysis was performed using SAS (Statistical Analysis System) software, 9.2 version.

\section{Results and discussion}

The results found for the centesimal composition of Pereskia aculeata (Table 1) show that the species presented all the investigated nutrients. Their comparison with other results was difficult since studies on the nutritional potential of this species are still minimal. At the same time, Pereskia aculeata is the only edible species within the genus Pereskia, which makes the comparison even more difficult, at least, with other species of the same botanical similarity.

By comparing the results of this study with those found by Takeiti et al. (2009) in Pereskia aculeata collected in Serra da Cantareira, São Paulo, Brazil, a difference can be seen among the results found by these authors, since they found concentration

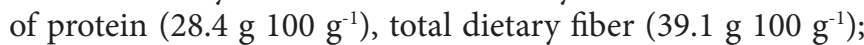

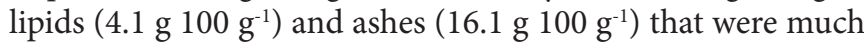
higher than those found in this study. 
The possible difference between these results and those of the present study may be related to the fact that Takeiti et al. (2009) analyzed the in vitro digestibility of proteins as well as dietary fibers, lipids and ashes by the American Association of Cereal Chemists method, whose methodology differs from that used in the present study.

According to the Food Guide for the Brazilian Population, a portion of vegetables is equivalent to $30 \mathrm{kcal}$ (Brasil, 2008). Considering these recommendations, a portion of Pereskia aculeata $(90 \mathrm{~g}$ ) contains $2.54 \mathrm{~g}$ of total dietary fiber $3.67 \mathrm{~g}$ of carbohydrates and $1.93 \mathrm{~g}$ of proteins. So, this vegetable may contribute with $7 \%, 3 \%$ and $4 \%$ of RDA for adults, respectively.

Considering the methodology proposed by Philippi (2008) for classifying foods in source, good source or excellent source of some nutrient, it can be considered that Pereskia aculeata is a source of total dietary fiber for providing $7 \%$ of this nutrient according to the $R D A$.

According to Figure 1 and Table 2, it is observed that Pereskia aculeata presented carotenoids and vitamin E, however vitamin $\mathrm{C}$ was not found. These results differ from those found by Oliveira et al. (2013), who found $192.2 \mathrm{mg} 100 \mathrm{~g}^{-1}$ of ascorbic acid in leaves of Pereskia aculeata collected in the State of Mato Grosso, Brazil. However, these authors analyzed these concentrations using the spectrophotometric method, which is different from the methodology used in the present study.

Agostini-Costa et al. (2012) used the analysis method which was also used in this study to evaluate the concentration of carotenoids in Pereskia aculeata. However, those authors analyzed the fruits and found lower concentrations of $\alpha$-carotene $\left(0.022 \mathrm{mg} 100 \mathrm{~g}^{-1}\right)$. In this same study, the authors found $\beta$-crytoxanthin $\left(0.002 \mathrm{mg} 100 \mathrm{~g}^{-1}\right)$, which was different from what occurred in the present study, where this compound was not found.

Studies that analyzed vitamin E in Pereskia aculeata were not found. In the present study, $a--$ tocopherol was the major component (400.34 $\mu \mathrm{g} 100 \mathrm{~g}^{-1}$ ), representing 91\% among the analyzed compounds.

By considering the recommendations of the Food Guide for the Brazilian Population (Brasil, 2008), a portion of Pereskia aculeata is equivalent to $90 \mathrm{~g}$, and it may contribute with $22 \%$ of the vitamin A required daily, so that it can be considered an excellent source of this nutrient. In relation to vitamin E, a portion of Pereskia aculeata ( $0.36 \mathrm{~g}$ of this nutrient) cannot be considered as a source of this nutrient, since its contribution percentage is of only $2 \%$.

Among the investigated minerals, the concentrations of $\mathrm{K}, \mathrm{Ca}$ and $\mathrm{Mg}$ stood out. Chromium and Mo were not identified in Pereskia aculeata samples (Table 3). Oliveira et al. (2013) investigated the occurrence of some minerals in Pereskia aculeata leaves using atomic absorption spectrophotometry, and found results, on average, six times higher than those found in the present study for K (3740 mg $\left.100 \mathrm{~g}^{-1}\right)$, Ca (2160 mg $\left.100 \mathrm{~g}^{-1}\right)$, $\mathrm{Mg}$ (680 mg $\left.100 \mathrm{~g}^{-1}\right)$ and $\mathrm{Cu}(0.9 \mathrm{mg} 100 \mathrm{~g}-1)$. Takeiti et al. (2009) also quantified minerals in Pereskia aculeata and found higher results than those found in this study for $\mathrm{Ca}\left(3420 \mathrm{mg} 100 \mathrm{~g}^{-1}\right)$, $\mathrm{Mg}\left(1900 \mathrm{mg} 100 \mathrm{~g}^{-1}\right), \mathrm{K}\left(1632 \mathrm{mg} 100 \mathrm{~g}^{-1}\right)$, Mn (46.4 mg $\left.100 \mathrm{~g}^{-1}\right)$, $\mathrm{Zn}\left(26.7 \mathrm{mg} 100 \mathrm{~g}^{-1}\right)$ and $\mathrm{Cu}\left(1.4 \mathrm{mg} 100 \mathrm{~g}^{-1}\right)$.

The difference in the concentration of the minerals found by these authors in relation to the present work can be attributed to the differences in the botanical structure of native plants. Since

Table 1. Centesimal composition, caloric value and nutritional contribution potential for adults (19 to 30 years old) in Pereskia aculeata.

\begin{tabular}{|c|c|c|c|}
\hline \multirow{2}{*}{ Variables } & \multirow{2}{*}{ Mean \pm standard deviation } & \multicolumn{2}{|c|}{ Contribution potential $\left(1\right.$ portion $\left.=90 \mathrm{~g}^{1}\right)$} \\
\hline & & g/portion & $\%^{2}$ \\
\hline Moisture (g $\left.100 \mathrm{~g}^{-1}\right)$ & $91.10 \pm 2.24$ & - & - \\
\hline Total dietary fiber $\left({\left.\mathrm{g} 100 \mathrm{~g}^{-1}\right)}\right.$ & $3.73 \pm 0.03$ & 2.54 & 7 \\
\hline $\operatorname{Ash}\left(\mathrm{g} 100 \mathrm{~g}^{-1}\right)$ & $0.96 \pm 0.01$ & - & - \\
\hline Carbohydrates (g $\left.100 \mathrm{~g}^{-1}\right)$ & $2.87 \pm 0.61$ & 3.67 & 3 \\
\hline Lipids $\left(\mathrm{g} 100 \mathrm{~g}^{-1}\right)$ & $1.45 \pm 0.01$ & - & - \\
\hline Proteins $\left(\mathrm{g} 100 \mathrm{~g}^{-1}\right)$ & $1.27 \pm 0.07$ & 1.93 & 4 \\
\hline Caloric value (kcal $100 \mathrm{~g}^{-1}$ ) & $29.17 \pm 3.28$ & - & - \\
\hline
\end{tabular}

Values expressed in fresh matter; mean of three replicates; ${ }^{1}$ vegetable portion equivalent to $30 \mathrm{kcal}$ (Brasil, 2008); ${ }^{2}$ calculated on the basis of $R D A$ for $19-30$-year-old adults (Institute of Medicine, 2001).

(A)

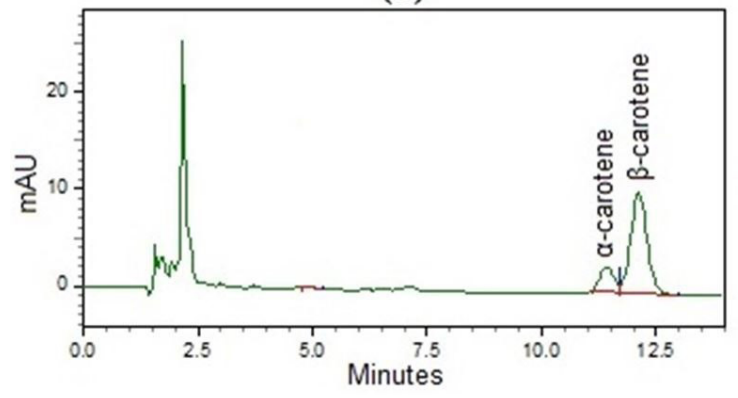

(B)

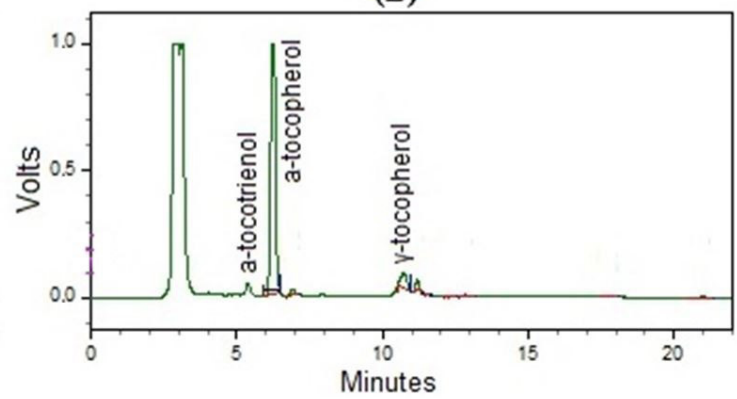

Figure 1. Chromatographic profile of carotenoids (A) and vitamin E (B) found in Pereskia aculeata. 
Table 2. Concentration of carotenoids and vitamins and nutritional contribution potential for adults (19 to 30 years old) in Pereskia aculeata.

\begin{tabular}{|c|c|c|c|c|}
\hline \multirow{2}{*}{ Compounds } & \multirow{2}{*}{ Mean \pm standard deviation } & \multirow{2}{*}{$\%$} & \multicolumn{2}{|c|}{ Contribution potential $\left(1\right.$ portion $\left.=90 \mathrm{~g}^{1}\right)$} \\
\hline & & & g/portion & $\%^{2}$ \\
\hline Total carotenoids (mg $100 \mathrm{~g}^{-1}$ ) & $3.15 \pm 0.14$ & 100 & & \\
\hline a-carotene $\left(\mathrm{mg} 100 \mathrm{~g}^{-1}\right)$ & $0.97 \pm 0.08$ & 30 & & \\
\hline$\beta$-criptoxanthin $\left(m g 100 g^{-1}\right)$ & nd & -- & & \\
\hline Licopene $\left(m g 100 g^{-1}\right)$ & nd & -- & & \\
\hline Ascóribic acid & nd & -- & & \\
\hline Dehydroascorbic acid & nd & -- & & \\
\hline Total vitamin $\mathrm{E}\left(\mu \mathrm{g} 100 \mathrm{~g}^{-1}\right)$ & $438.68 \pm 33.62$ & 100 & 0.36 & $2^{3}$ \\
\hline$\alpha$-tocopherol $\left(\mu \mathrm{g} 100 \mathrm{~g}^{-1}\right)$ & $400.34 \pm 29.65$ & 91 & & \\
\hline$\alpha$-tocotrienol $\left(\mu \mathrm{g} 100 \mathrm{~g}^{-1}\right)$ & $10.98 \pm 0.27$ & 3 & & \\
\hline$\delta$-tocopherol $\left(\mu \mathrm{g} 100 \mathrm{~g}^{-1}\right)$ & nd & -- & & \\
\hline$\delta$-tocotrienol $\left(\mu \mathrm{g} 100 \mathrm{~g}^{-1}\right)$ & nd & -- & & \\
\hline
\end{tabular}

Table 3. Mineral concentration and nutritional contribution potential for adults (19 to 30 years old) in Pereskia aculeata.

\begin{tabular}{ccc}
\hline Minerals $\left({\left.\mathrm{mg} 100 \mathrm{~g}^{-1}\right)}^{-1} \begin{array}{c}\text { Mean } \pm \text { standard } \\
\text { deviation }\end{array}\right.$ & $\begin{array}{c}\text { Contribution } \\
\text { potential }\left(\%{ }^{1}\right)\end{array}$ \\
\hline $\mathrm{K}$ & $689.41 \pm 18.53$ & 15 \\
$\mathrm{Ca}$ & $427.08 \pm 9.9$ & 38 \\
$\mathrm{Mg}$ & $88.84 \pm 19.62$ & 20 \\
$\mathrm{Cu}$ & $0.12 \pm 0.03$ & 12 \\
$\mathrm{Fe}$ & $13.89 \pm 3.34$ & 156 \\
$\mathrm{Zn}$ & $0.05 \pm 0.02$ & 0.4 \\
$\mathrm{Mn}$ & $3.46 \pm 0.02$ & 135 \\
$\mathrm{Na}$ & $1.19 \pm 0.66$ & 0.07 \\
$\mathrm{Cr}$ & $\mathrm{nd}$ & -- \\
$\mathrm{Se}$ & $0.13 \pm 0.01$ & 213 \\
$\mathrm{Mo}$ & $\mathrm{nd}$ & -- \\
\hline
\end{tabular}

Values expressed in dry matter; mean of three replicates; ${ }^{1}$ calculated on the basis of RDA for 19-30-year-old adults (Institute of Medicine, 2001).

they are collected in natural environments and there is no control of environmental factors such as water, light and temperature, as well as the mineral composition of the soil where these plants are grown, as observed in a study by Subramanian et al. (2012) on the analysis of minerals and heavy metals in some medicinal plants collected at a local market in Salem, India.

By analyzing the contribution potential of the minerals investigated in this study (Table 3), it is observed that Pereskia aculeata may be considered a good source of $\mathrm{K}$ and $\mathrm{Cu}$, and an excellent source of $\mathrm{Ca}, \mathrm{Mg}, \mathrm{Fe}, \mathrm{Mn}$ and Se. However, even if the contribution potential of some minerals is above the RDA, it is stressed that the mineral concentration is not a conclusive indicator of the amount absorbed and used by the organism. Therefore, it is necessary to evaluate the antinutritional factors of this vegetable, since studies with those objectives are not found.

\section{Conclusions}

High concentrations of micronutrients were found in Pereskia aculeata, which was also a source of total dietary fiber a good source of $\mathrm{K}$ and $\mathrm{Cu}$, and an excellent source of vitamin A, Ca, Mg, Fe, Mn and Se.

The occurrence of this species in native environments of the Brazilian Atlantic Forest becomes important since it is part of the dietary habits of the families that live there, mainly and due to its important potential of nutritional contribution, making Pereskia aculeata a fundamental food species for the strategies of food and nutritional security of family groups whose eating habits are directly related to the consumption of this species.

\section{Acknowledgements}

The authors thank the National Council for Scientific and Technological Development (CNPq, Brazil), Coordination of Improvement of Higher Level Personnel (CAPES, Brazil), Foundation for Research Support of the State of Minas Gerais (FAPEMIG, Brazil) and Arthur Bernardes Foundation (FUNARBE, Brazil) for granting scholarships and for the financial support for the achievement of this study.

\section{References}

Agostini-Costa, T. S., Wondraceck, D. C., Rocha, W. S., \& Silva, D. B. (2012). Carotenoids profile and total polyphenols in fruits of Pereskia aculeata Miller. Revista Brasileira de Fruticultura, 34(1), 234-238. http://dx.doi.org/10.1590/S0100-29452012000100031.

Association of Official Analytical Chemists - AOAC. (2010). Official methods of analysis (1170 p.). Gaithersburg: AOAC.

Barreira, T. F., Paula, G. X. Fo., Rodrigues, V. C. C., Andrade, F. M. C., Santos, R. H. S., Priore, S. E., \& Pinheiro-Sant'Ana, H. M. 
(2015). Diversidade e equitabilidade de plantas alimentícias não convencionais na zona rural de Viçosa, Minas Gerais, Brasil. Revista Brasileira de Plantas Medicinais, 17(4 Suppl. 2), 964-974. http:// dx.doi.org/10.1590/1983-084X/14_100.

Brasil. (2008). Guia alimentar para a população brasileira: promovendo a alimentação saudável. Brasília: Ministério da Saúde.

Campos, F. M., Ribeiro, S. M. R., Della-Lucia, C. M., Pinheiro-Sant'Ana, H. M., \& Stringheta, P. C. (2009). Optimization of methodology to analyze ascorbic and dehydroascorbic acid in vegetables. Química Nova, 32(1), 87-91. http://dx.doi.org/10.1590/S0100-40422009000100017.

Carvalho, E. G., Soares, C. P., Blau, L., Menegon, R. F., \& Joaquim, W. M. (2014). Wound healing properties and mucilage content of Pereskia aculeata from different substrates. Revista Brasileira de Farmacognosia, 24(6), 677-682. http://dx.doi.org/10.1016/j.bjp.2014.11.008.

Frary, C. D., \& Johnson, R. K. (2005). Energia. In L. K. Mahan \& S. Escott-Stump (Eds.), Krause: alimentos, nutrição e dietoterapia (pp. 20-34). São Paulo: Rocca.

Gomes, J. C., \& Oliveira, G. F. 2011. Fotometria de chama e espectrofotometria de absorção atômica. In J. C. Gomes \& G. F. Oliveira (Eds.), Análises físico-químicas de alimentos: fotometria de chama e espectrofotometria de absorção atômica (pp. 47-52). Viçosa: UFV.

Guerra, N. B., David, P. R. B. S., Melo, D. D., Vasconcelos, A. B. B., \& Guerra, M. R. M. (2004). Modificações do método gravimétrico não enzimático para determinar fibra alimentar solúvel e insolúvel em frutos. Revista de Nutrição, 17(1), 45-52. http://dx.doi.org/10.1590/ S1415-52732004000100005.

Institute of Medicine - IOM. (2001). Dietary reference intakes for vitamin $A$, vitamin $K$, arsenic, boron, chromium, copper, iodine, iron, manganese, molybdenum, nickel, silicon, vanadium, and zinc (773 p.). Washington: IOM.

Oliveira, D. C. S., Wobeto, C., Zanuzo, M. R., \& Severgnini, C. (2013). Mineral composition and ascorbic acid content in four nonconventional leafy vegetables species. Horticultura Brasileira, 31(3), 472-475. http://dx.doi.org/10.1590/S0102-05362013000300021.
Paula, G. X. Fo., Barreira, T. F., Rodrigues, V. C. C., Cardoso, L. M., Martino, H. S. D., \& Pinheiro-Sant'Ana, H. M. (2015). Study of the physical and physicochemical characteristics of fruits of the licuri palm (Syagrus coronata (Mart.) Becc.) found in the Atlantic Forest of Minas Gerais, Brazil. Food Science and Technology, 35(3), 474480. http://dx.doi.org/10.1590/1678-457X.6652.

Philippi, S. T. (2008). Pirâmide dos alimentos: fundamentos básicos da nutrição (1st ed.). Barueri: Manole.

Pinheiro-Sant'Ana, H. M., Guinazi, M., Oliveira, D. S., Della Lucia, C. M., Reis, B. L., \& Brandão, S. C. (2011). Method for simultaneous analysis of eight vitamin $\mathrm{E}$ isomers in various foods by high performance liquid chromatography and fluorescence detection. Journal of Chromatography A, 1218(47), 8496-8502. http://dx.doi. org/10.1016/j.chroma.2011.09.067. PMid:22014383.

Pinto, N. C. C., Machado, D. C., Silva, J. M., Conegundes, J. L. M., Gualberto, A. C. M., Gameiro, J., Moreira Chedier, L., Castañon, M. C. M. N., \& Scio, E. (2015). Pereskia aculeata Miller leaves present in vivo topical anti-inflammatory activity in models of acute and chronic dermatitis. Journal of Ethnopharmacology, 173, 330-337. http://dx.doi.org/10.1016/j.jep.2015.07.032. PMid:26226436.

Rodriguez-Amaya, D. B., Raymundo, L. C., Lee, T., Simpson, K. L., \& Chichester, C. O. (1976). Carotenoid pigment changes in ripening Momordica charantia fruits. Annali di Botanica, 40(3), 615-624. http://dx.doi.org/10.1093/oxfordjournals.aob.a085171.

Subramanian, R., Gayathri, S., Rathnavel, C., \& Raj, V. (2012). Analysis of mineral and heavy metals in some medicinal plants collected from local market. Asian Pacific Journal of Tropical Biomedicine, 2(1), 74-78. http://dx.doi.org/10.1016/S22211691(12)60133-6.

Takeiti, C. Y., Antonio, G. C., Motta, E. M. P., Collares-Queiroz, F. P., \& Park, K. J. (2009). Nutritive evaluation of a non-conventional leafy vegetable (Pereskia aculeata Miller). International Journal of Food Sciences and Nutrition, 60(Suppl. 1), 148-160. http://dx.doi. org/10.1080/09637480802534509. PMid:19468927. 